\title{
The seroprevalence of hepatitis $B$ and $C$ in an Amerindian population in the southwestern Brazilian Amazon
}

\author{
Soroprevalência da hepatite B e C em uma população indígena \\ da Amazónia Sul-Ocidental Brasileira
}

J.O. Ferrari, M.U. Ferreira, A. Tanaka and M. Mizokami

\begin{abstract}
We have investigated the seroprevalence of hepatitis $B$ and $C$ among Karitiana Indians $(n=119)$ living in the State of Rondônia, southwestern Brazilian Amazon. The prevalences of anti-HBs and anti-HBc were $16.1 \%$ and $35.3 \%$, respectively, with HBsAg being found in only four (3.4\%) subjects. Anti-HCV antibodies were detected in two subjects (1.7\%). Age-stratified prevalence data suggest that both vertical and horizontal (the last among adults) routes of HBV transmission are important in this community.
\end{abstract}

Key-words: Hepatitis B and C. Epidemiology. Amazonian Indians.

Resumo A soroprevalência de hepatite $B$ e $C$ foi investigada na comunidade indígena Karitiana ( $n=119)$, que habita o Estado de Rondônia, Amazônia Ocidental Brasileira. A prevalência de anticorpos anti-HBs e anti-HBc foi respectivamente de $16,1 \%$ e 35,3\%, sendo detectado HBsAg em somente quatro (3,4\%) indivíduos. Anticorpos anti-HCV foram encontrados em dois $(1,7 \%)$ indivíduos. Os dados estratificados por idade sugerem que tanto as vias de transmissão vertical como horizontal (esta entre adultos) são importantes nesta comunidade.

Palavras-chaves: Hepatite B e C. Epidemiologia. Índios amazônicos.

Several recent surveys have disclosed high seroprevalences of hepatitis B virus (HBV) and hepatitis delta virus (HDV) infection in both urban and rural communities within the Brazilian Amazon 59 , especially in the western part of this vast region 41215 . Few of these studies have simultaneously assessed the prevalence of hepatitis $\mathrm{C}$ virus (HCV), but the available data indicate that $\mathrm{HCV}$ infection remains relatively uncommon in this area 17.

Native Amerindians of diverse ethnic groups are among the populations with the highest prevalence of HBV infection in the Amazon3 67131415161718 . Among them, positivity rates of hepatitis $B$ surface antigen (HBsAg) may exceed 10\%3 $67 \begin{array}{llllll}13 & 14 & 15 & 16 & 17 .\end{array}$ These findings have been explained by either the relatively low level of genetic variability in Amerindian populations, leading to universally increased predisposition to certain infections 15 , or the occurrence of alternative routes of horizontal HBV transmission, involving bloodsucking mechanical vectors 3 and cultural practices such as skin scarification and tattooing7. There is, however, substantial regional and sometimes small-area variation in the prevalence of viral hepatitis across the Brazilian Amazon15. For instance, Amerindians who belong to the same

National Indian Foundation, Porto Velho, Rondônia, and Department of Parasitology, Institute for Biomedical Sciences, University of São Paulo, Brazil, Second Department of Medicine, Nagoya City University Medical School, Nagoya, Japan.

Financial support: M.U. Ferreira was a recipient of a graduate research student scholarship from the Japan's Ministry of Education, Science, Sports and Culture (1995-97).

Address to: Dr. Marcelo Urbano Ferreira, Departamento de Parasitologia, ICB/USP.Av. Prof. Lineu Prestes 1374, 05508-900 São Paulo, SP, Brazil, Tel.: 55-11-8187330, Fax: 55-11-8187417

E-mail: muferrei@usp.br.

Recebido para publicação em 14/7/98. 
linguistic group, share the same cultural practices and live in nearby villages may present quite different prevalence rates of HBV markers 17 . The differential prevalences of HBV infection in communities exposed to varying environmental conditions and cultural practices may provide insights into the relative importance of these factors in horizontal HBV transmission in highly endemic areas such as the Amazon Basin. Thus, the present communication describes the prevalence of $\mathrm{HBV}$ and $\mathrm{HCV}$ infection among Karitiana Indians living in the southwestern Brazilian Amazon.

The Karitiana Indian Reservation occupies an area of 89,862 hectares covered with rain forest $\left(64^{\circ} 15^{\prime} \mathrm{W}, 9^{\circ} 30^{\prime} \mathrm{S}\right)$ situated $90 \mathrm{~km}$ southwest of Porto Velho, the capital of the State of Rondônia, in the southwestern Brazilian Amazon. The Karitiana Indians are members of the TupiArikén linguistic family who have been living in the same area since the early 1960s. At the time of the field survey, 152 people were present in the reservation, all of them inhabiting the same village situated on the banks of the Sapoti stream. As part of an extensive morbidity investigation, a cross-sectional seroepidemiologic survey was performed in this village in September 19941011. A health questionnaire was completed for all 152 inhabitants (72 males and 80 females). The ages of all children and most adults were calculated from the date of birth as recorded in official documents (birth certificates or identification cards), but for some older people only selfreported ages were available.

After informed consent of donors, their parents or guardians, venous blood samples were collected from 138 people for plasma separation. Children below one year of age $(n=4)$ and people who refused or were unable to participate ( $n=10$ ) were excluded from blood collection, and 19 people were excluded from HBV and HCV marker testing because of the low available sample volumes. The study population $(n=119)$ consisted of 55 males and 64 females aged 1-76 years (mean, $18.0 \pm 7.8$ [SD] years), who corresponded to $78 \%$ of the total population. Plasma samples were stored at $-20^{\circ} \mathrm{C}$ until tested. They were screened for HBV markers (HBsAg and antibodies to HBV surface antigen [antiHBs] and core antigen [anti-HBc]) by radioimmunoassay, for anti-HCV antibodies by second-generation enzyme immunoassay (ELISAII) and for anti-human immunodeficiency virus (HIV) by enzyme immunoassay using commercially available kits (Abbott/Dainabot Laboratories, Tokyo, Japan). Prevalence rates are presented with $95 \%$ confidence intervals and compared with $\chi^{2}$ tests. Significance was defined at the $5 \%$ level.

Table 1 presents the age-stratified prevalence rates of HBV markers in the population under study. The overall prevalence rates of anti-HBs and anti-HBc antibodies were $16.1 \%(95 \%$ confidence interval: $10.2-24.3 \%$ ) and $35.3 \%$

Table 1 - Prevalence of hepatitis B virus (HBV) infection markers in Karitiana Amerindians according to age.

\begin{tabular}{|c|c|c|c|c|c|c|c|c|c|c|}
\hline \multirow{2}{*}{$\begin{array}{l}\text { Age } \\
\text { (years) }\end{array}$} & \multirow{2}{*}{$\begin{array}{c}\text { Total } \\
\text { populationa }\end{array}$} & \multirow{2}{*}{$\begin{array}{c}\text { № } \\
\text { examinedb }\end{array}$} & \multicolumn{2}{|c|}{$\mathrm{HbsAg}$} & \multicolumn{2}{|c|}{ anti-HBs } & \multicolumn{2}{|c|}{ anti-HBc } & \multicolumn{2}{|c|}{$\begin{array}{l}\text { At least one } \\
\text { HBV marker }\end{array}$} \\
\hline & & & $\mathrm{n}$ & $\%$ & $\mathrm{n}$ & $\%$ & $\mathrm{n}$ & $\%$ & $n$ & $\%$ \\
\hline$<1$ & 4 & 0 & - & - & - & - & & & & \\
\hline $1-6$ & 41 & 32 & 0 & 0 & 9 & 28.1 & 2 & 6.2 & 10 & 31.2 \\
\hline $7-15$ & 42 & 37 & 2 & 5.4 & 6 & 16.2 & 10 & 27.0 & 14 & 37.8 \\
\hline $16-29$ & 38 & 33 & 1 & 3.0 & 3 & 9.1 & 12 & 36.4 & 13 & 39.4 \\
\hline$\geq 30$ & 27 & 18 & 1 & 5.5 & 1 & $5.9 c$ & 18 & 100.0 & 18 & 100.0 \\
\hline Total & 152 & 119 & 4 & 3.4 & 19 & 16.1 & 42 & 35.3 & 55 & 46.2 \\
\hline
\end{tabular}

a 72 males and 80 females; b 55 males and 64 females and c one subject not tested for anti-HBs in this age group.

(26.9-44.6\%), respectively. HBsAg was detected in only four subjects [3.4\% $(1.1-8.9 \%)]$, and at least one HBV marker was found in $46.2 \%$ $(37.1-55.6 \%)$ of the subjects. A previous study detected lower prevalence rates of anti-HBs antibodies $(5 \%, 5 / 98)$ and $\mathrm{HBsAg}(0 / 98)$ in this community, but age-stratified rates were not given 15. The prevalence of HBV markers was higher in females [53.1\% (40.3-65.5\%)] than in males [38.2\% (25.7-52.3\%)], but this difference was not statistically significant (age-stratified Mantel-Haenzel $\chi^{2}=2.32,1$ d. f., $p=0.128$ ). Anti-HCV antibodies, that had not been previously investigated in this community ${ }^{15}$, were found in 
only two indviduals $[1.7 \%(0.3-6.5 \%)]$. These cases were not further investigated by confirmatory polymerase chain reaction since adequate sample volumes for viral RNA extraction were not available. Plasma samples were not tested for anti-HDV antibodies. All samples were negative for anti-HIV antibodies.

The prevalence of HBV markers was already high $(>30 \%)$ in the youngest age group (1-6 years), remained relatively unchanged $(<40 \%)$ until the age of 29 years, and then sharply increased to $100 \%$ (Table 1). This indicates that a considerable proportion of HBV infections among the Karitiana is acquired in early childhood, probably as a result of vertical transmission. Most of the remaining infections seem to be contracted after subjects start sexual activity. These findings contrast with both the slow but constant age-related increase in HBV prevalence found in an urban population of low endemicity in the northwestern Brazilian Amazon?, and with the sharp increase in HBV prevalence throughout childhood found among the Txucarramãe living in the highly endemic Xingu Park, Central Brazil3. Within this context, the Karitiana provide an interesting example of an Amerindian population with limited genetic variability 1 but without high-risk practices potentially leading to HBV infection, such as skin scarification, body piercing and tattooing.

Three HBsAg carriers belong to the same nuclear family. The 39-year-old father and two children (a male aged 14 years and a female aged 11 years) were also anti-HBc positive. Their mother was negative for all HBV markers, challenging the hypothesis of vertical transmission in this case. The other HBsAg carrier was a 29-year-old female, anti-HBc negative. She has five children (age range: 3-14 years), all of them negative for HBV markers. Similar patterns of familial aggregation of HBV infection have been found in other endemic areas. 8 .

Table 2 presents the HBV marker status of mothers of children aged 1-10 years who were positive for at least one HBV marker. Note that these 11 children are clustered into six nuclear families and that all mothers had anti-HBc antibodies but no other HBV infection marker. These findings are compatible with past HBV infection, but also with either low titers of anti$\mathrm{HBs}$ or HBsAg or a false-positive test for anti$\mathrm{HBc}$ antibodies. The mothers of seven other positive children in this age group could not be identified or were not tested for HBV markers.

In conclusion, the overall seroprevalence of HBV among the Karitiana is lower than those commonly reported for Amerindian communities, but still higher than those found in most urban communities in the Amazon. Both vertical and sexual routes of HBV transmission seem to be important in this community, and age-stratified prevalence data do not suggest the frequent occurrence of alternative routes of horizontal transmission among children.

Table 2 - HBV status of mothers of children aged 1-10 years who were positive for at least one HBV marker.

\begin{tabular}{|c|c|c|c|c|c|c|c|c|}
\hline \multicolumn{4}{|c|}{ Mother } & \multicolumn{5}{|c|}{ Child } \\
\hline $\begin{array}{l}\text { Age } \\
\text { (years) }\end{array}$ & $\mathrm{HbsAg}$ & anti-HBs & anti-HBc & $\begin{array}{c}\text { Age } \\
\text { (years) }\end{array}$ & Sex & $\mathrm{HbsAg}$ & anti-HBs & anti-HBc \\
\hline 40 & - & - & + & 2 & $M$ & - & + & - \\
\hline As above & & & & 6 & M & - & + & - \\
\hline As above & & & & 10 & $\mathrm{~F}$ & - & + & - \\
\hline 29 & - & - & + & 4 & $M$ & - & + & - \\
\hline As above & & & & 5 & $\mathrm{~F}$ & - & + & - \\
\hline 27 & - & - & + & 5 & $\mathrm{~F}$ & - & + & - \\
\hline As above & & & & 7 & $\mathrm{~F}$ & - & + & + \\
\hline 30 & - & - & + & 5 & $\mathrm{~F}$ & - & + & - \\
\hline As above & & & & 8 & $\mathrm{~F}$ & - & + & - \\
\hline 37 & - & - & + & 9 & M & - & + & - \\
\hline 19 & - & - & + & 5 & $\mathrm{~F}$ & - & + & - \\
\hline
\end{tabular}

$\mathrm{M}=$ male and $\mathrm{F}=$ female.

\section{ACKNOWLEDGEMENT}

The staff of the National Indian Foundation (FUNAI) at Porto Velho, Rondônia State, Brazil, is gratefully acknowledged for skilled help during field work. 


\section{REFERENCES}

1. Aguiar GFS. Sociocultural factors and the genetic diversification of Amazonian Indians: a brief overview. Social Biology 40: 38-47, 1993.

2. Arboleda M, Castilho MC, Fonseca JCF, Albuquerque BC, Sabóia RC, Yoshida CFT. Epidemiological aspects of hepatitis $B$ and $D$ virus infection in the northern region of Amazonas, Brazil. Transactions of the Royal Society of Tropical Medicine and Hygiene 89: 481-483, 1995.

3. Azevedo RA, Silva AE, Ferraz MLG, Marcopito LF, Baruzzi RG. Prevalência dos marcadores sorológicos dos vírus da hepatite $B$ e $D$ em crianças das tribos Caiabi e Txucarramãe do Parque Indígena do Xingu, Brasil Central. Revista da Sociedade Brasileira de Medicina Tropical 29: 431-439, 1996.

4. Bensabath G, Hadler SC, Soares MC, Fields H, Dias LB, Popper H, Maynard JE. Hepatitis Delta virus infection and Labrea hepatitis: prevalence and role in fulminating hepatitis in the Amazon Basin. Journal of the American Medical Association 258: 479-483, 1987.

5. Bensabath G, Soares MCP, Cartágenes PR, Dias LC. Patologia tropical na Amazônia. Hepatites B e D. Febre Negra de Lábrea. In: Veronesi R, Focaccia R (eds) Tratado de Infectologia. Atheneu, São Paulo, p. 14811484, 1996.

6. Black FL, Pandey JP, Capper RA. Hepatitis B epidemiology and its relation to immunogenetic traits in South American Indians. American Journal of Epidemiology 123: 336-343, 1986.

7. Coimbra Jr CEA, Santos RV, Yoshida CFT, Baptista ML, Flowers NM, Valle ACF. Hepatitis B epidemiology and cultural practices in Amerindian populations of Amazonia: the Tupi-Mondé and the Xavánte from Brazil. Social Science and Medicine 42: 1738-1743, 1996.

8. Edmunds WJ, Medley GF, Nokes DJ, O'Callaghan CJ, Whittle HC, Hall AJ. Epidemiological patterns of hepatitis $B$ virus (HBV) in highly endemic areas. Epidemiology and Infection 117: 313-325, 1996.

9. Fay $\mathrm{OH}$. Hepatitis B in Latin America: epidemiological patterns and eradication strategy. The Latin American Regional Study Group. Vaccine 8 (suppl): S100-S106, 1990.
10. Ferrari JO. Asaúde dos índios: um desafio sem endereço. Os Karitiana de Rondônia. Dissertação de Mestrado, Universidade de São Paulo, São Paulo, 1996.

11. Ferreira MU, Kimura EAS, Katzin AM, Santos-Neto LL, Ferrari JO, Villalobos JM, Carvalho ME. The IgG-subclass distribution of naturally acquired antibodies to Plasmodium falciparum, in relation to malaria exposure and severity. Annals of Tropical Medicine and Parasitology 92:245256, 1998.

12. Fonseca JFC, Simonetti SRR, Schatzmayr HG, Castejón MJ, Cesário ALO, Simonetti JP. Prevalence of infection with hepatitis delta virus (HDV) among carriers of hepatitis B surface antigen in Amazon State, Brazil. Transactions of the Royal Society of Tropical Medicine and Hygiene 82: 469-471, 1988.

13. Franco VS, Guimarães RX, Franco LJ, Baruzzi RG, Novo NF. Marcadores sorológicos da hepatite viral B e alfa 1 antitripsina em índios da tribo Mekranhotire. Revista Paulista de Medicina 103: 223-227, 1985.

14. Gayotto LCC, Quarentei AA, Cabral GL. Soroepidemiologia das hepatites Ae B nas regiões dos Rios Biá e Alto Juruá, Amazônia Ocidental. Gastroenterologia e Endoscopia Digestiva 3: 106-112, 1984.

15. Santos AKCR, Ishak MOG, Santos SEB, Ishak R. A possible correlation between the host genetic background in the epidemiology of hepatitis B virus in the Amazon Region of Brazil. Memórias do Instituto Oswaldo Cruz 90: 435-441, 1995.

16. Soares MCP, Bensabath G. Tribos indígenas da Amazônia Oriental como população de risco para a hepatite D (Delta). Revista do Instituto de Medicina Tropical de São Paulo 33: 241-242, 1991.

17. Soares MCP, Menezes RC, Martins SJ, Bensabath G. Epidemiologia dos vírus das hepatites $\mathrm{B}, \mathrm{C}$ e $\mathrm{D}$ na tribo indígena Parakanã, Amazônia Oriental Brasileira. Boletín de la Oficina Sanitaria Panamericana 117: 124-135, 1994.

18. Vieira-Filho JB, Cruz CFN, Kemp L, Santos OM, Guimarães RX. Prevalência dos marcadores sorológicos do HBV em indígenas do Sudeste do Pará (PA). Gastroenterologia e Endoscopia Digestiva 9: 35-36, 1990. 